DOI: $10.35218 /$ armca.2021.1.10

\title{
Anatomical States - Between Pathology And Visual Expressiveness
}

\author{
Cezarina Florina Caloian*
}

\begin{abstract}
The topic of the article Anatomical states - between pathology and visual expressiveness may be further approached from several perspectives: the disease itself, transposed into images in various works of art as a symbol of human suffering, from the perspective of medical illustration or the rendition of medical acts, but also from the perspective of the suffering artists, who depicted their physical or mental traumas in their own paintings. In art, there are several recurring themes centred on the human body, such as: the death of the body versus the immortality of the soul, the young body as a symbol of beauty versus the aged body, the ability to control one's own body, self-preservation and survival instincts, the fight against disease, addictions and their impact on a person's health and state of mind.

The article discusses facets of the disease as well as visions of the human body captured in the visual arts, from the theme of the Danse Macabre in the Middle Ages to Dr. Tulp's Anatomy Lesson by Rembrandt or the aesthetic vision of Egon Schiele. Another topic approached is the correlation between emotional states and body attitudes or visual metaphors, by using art as a way to exorcise inner demons, in the conception of Van Gogh, Frida Kahlo or Käthe Kollwitz, or to test the limits of the human body, like in the works of Marina Abramovic.
\end{abstract}

Keywords: visual art; the human body; disease; facial expression; suffering; drama; artistic creation; the limits of the body.

\section{Introduction}

Man, with all his complexity - physical, mental, or spiritual - has been at the centre of artistic concerns since ancient times. In the $4^{\text {th }}$ century $\mathrm{BC}$ Polykleitos sculpted a statue, now referred to as The Canon, which contained the ideal proportions of the human body. Later, Vitruvius establishes the ideal proportions of the human body, and the Greek concept of kalokagatia (kalos - beautiful, aghatos - good, with positive values) promotes the idea of perfection, a combination between physical and moral traits. In general, beautiful refers to the balanced result of proportion and harmony, and ugly to "an imbalance in the organic relationship between the

* Assoc. Prof., PhD. George Enescu National University of Arts 
parts and the whole" ${ }^{1}$. When illness is rendered in art, we can talk of the imbalance of anatomical proportions, of all the features that we currently classify as physical disabilities, plagues, or epidemics, as well as various diseases that can harm the human being, both physically and mentally, in the course of life. After World War II, epidemiology began to pay less attention to infectious diseases (to which it owed its name) and focused on chronic diseases: cardiovascular, rheumatic, cancerous, respiratory diseases, and diabetes $^{2}$. By their very name, chronic diseases are long-term conditions which develop slowly in time, often without a cure, alleviated with medication and special medical techniques which ensure the patient's survival.

The theme may be further approached from several perspectives: the disease itself, transposed visually into various works of art as a symbol of human suffering, from the perspective of medical illustration or the rendition of medical acts, but also from the perspective of the suffering artists, who depicted their physical or mental traumas in their own paintings. Over the centuries, Hippocratic facies or the change in facial features produced by long-term illness, after a period of malnutrition, or before death, characterized by pallor, thinning features, sunken cheeks and eyes, has been a source of inspiration for artists. The signs of human suffering as a result of disease, plagues, natural or social disasters, wars, class struggle, antiSemitism, epidemics, or pandemics, events that produced millions of casualties, have been transposed into works of art.

\section{Facets of disease in the visual arts}

In Art as Therapy ${ }^{3}$, Alain de Botton and John Armstrong discuss seven functions of art from the perspective of the psychological features that it could address. The first, and perhaps one of its most important functions, is to remember, to keep in the common memory information about events, places, people, feelings and emotions, followed by hope - as an essential ingredient of success in the life of each individual. The third function is the ability to reproduce suffering, to mediate a state of mind, as Botton says, followed by the ability to rebalance, because art can give us concentrated doses of the states of mind we are lacking, restoring, to some extent, the balance of a drifting self. Another important function of art is selfunderstanding, its ability to promote self-knowledge, self-exploration, and

\footnotetext{
${ }^{1}$ Umberto Eco, Istoria Urâtului, Rao, București, 2007, p. 19

${ }^{2}$ Stéphane Audoin-Rouzeau, Antoine de Baecque, Annette Becker, Jean-Jacques Courtine, Frédéric Keck, Yves Michaud, Anne Marie Moulin, Pascal Ory, Paul Rabinow, Anne-Marie Sohn, Annie Suquet, Georges Vigarello, Istoria corpului, vol.III, Mutațiile privirii, $20^{\text {th }}$ century, Art Publishing, București, 2009, p. 118

${ }^{3}$ Alain de Botton, John Armstrong, Arta ca terapie, Vellant, București, 2018
} 
communicating our feelings and ideas to those around us, followed by emancipation, the people's ability to preserve their authenticity in dangerous situations: art presents us with ideas and attitudes that are not exactly at hand in our ordinary environment. Appreciation, the last function of art according to these two authors, is precisely its ability to emphasize the value or to facilitate the perception and understanding of essential things, enriching us spiritually. Of course, art serves the psychological, political, and commercial needs of a cultural area, at a certain time, mirroring the needs and coordinates of that age.

The very history of mankind, with its periods of flourishing and of great imbalance, is the mirror of the perpetual struggle between life and death. In the Middle Ages, during the bubonic plague, the theme of the Danse Macabre (or Dance of Death) appeared precisely to "exorcise fear and tame the final phenomenon" ${ }^{4}$. Its oldest representation, dating from 1424, preserved because it was engraved, was found in the Holy Innocents Cemetery in Paris, followed later on by the images signed by Hans Holbein during the Renaissance. These were published on leaflets or inside smallformat books, and depicted human beings and skeletons in various scenes, from the Bible or everyday life, in which death and life coexist. This theme was later taken over in painting by Pieter Bruegel the Elder in The Triumph of Death, 1562, Prado Museum, Madrid, but also by Charles Baudelaire in his poem of the same name, published in the volume Les Fleurs du Mal, in 1857. In the $17^{\text {th }}$ century, Peter Rubens depicts the bubonic plague through an allegory, The Miracles of Saint Francis Xavier, in which the saint, leading an army of angels, cures the sick of the plague. The disease is used here as a metaphor for heresy, and the plague becomes a symbol of $\sin ^{5}$. The plague hit Rubens' family very hard, as both he and his wife died of it. However, echoes of this epidemic are only vaguely found in his work, although it is known that together with two doctor friends he founded an association to take care of plague patients ${ }^{6}$.

Another work, entitled Allegory of love, signed by the Florentine painter Agnolo Bronzino in 1545, presents two distinct aspects: eroticism, in the relation between Venus and Cupid, and disease, as a result of passion. The character behind Cupid is in agony, most likely suffering from syphilis, as it is in fifteenth-century Spain that the first epidemic of this disease took place. The disease was brought to Barcelona by members of Christopher Columbus' crew, and later transmitted all over Europe by French soldiers ${ }^{7}$. The disease spread rapidly, affecting all walks of life, and was a major cause

\footnotetext{
${ }^{4}$ Eco Umberto, op. cit., p. 67

${ }^{5}$ M. Christine Bockl, Plague Imagery as Metaphor for Heresy in Ruben's The Miracles of Saint Francis Xavier, Sixteen Century Journal, XXVI.4 (1996), 979-995 JSTOR

${ }^{6}$ Ionela Bîlbîe Nosec, Arta - bucurie și suferință, Viața Medicală Românească, București, 2005

${ }^{7}$ Ibidem, p. 87
} 
of death. Cupid is depicted with a blackened leg, open ulcers and suffering from athlete's foot. This work is the only Renaissance representation of this skin disease ${ }^{8}$. The disaster caused by syphilis was translated into works of art by many artists and writers: Dürer in The Men's Bath (1496, Nuremberg Art Museum), François Rabelais, who, in the introduction to Gargantua and Pantagruel (1532), addresses the readers as "my drunk and syphilitic friends", and, later, William Hogarth in Gin Lane (1751), a work in which he shows a woman whose legs are covered in syphilitic lesions.

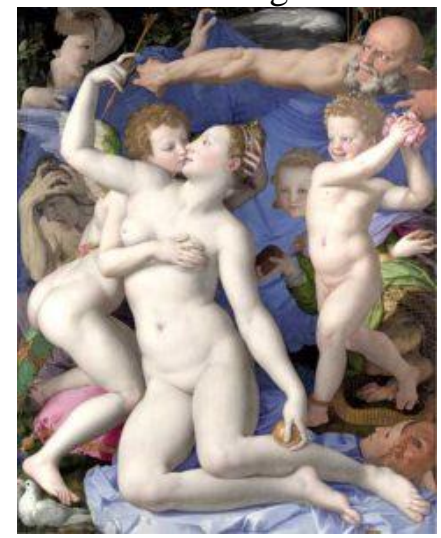

Fig. 1 Agnolo Bronzino, Allegory of love

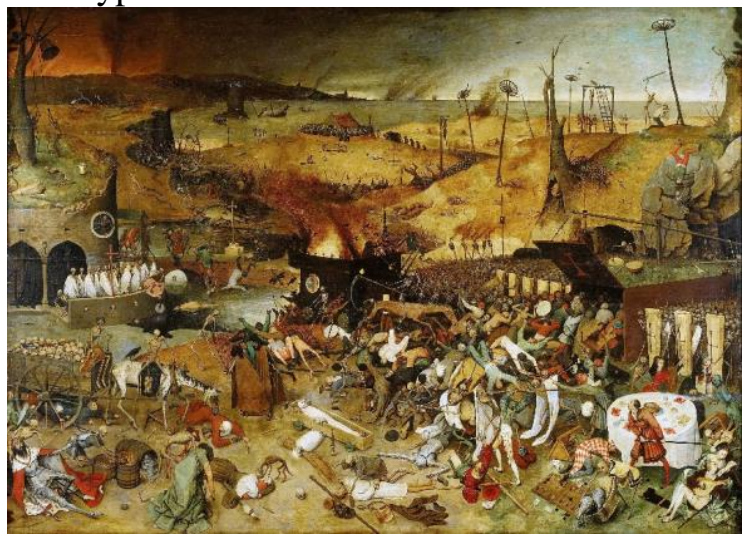

Fig. 2 Pieter Bruegel the Elder, The Triumph of Death

\section{Visions of the human body, between curiosity and science}

In the Middle Ages, the relationship between religion and medicine was very special; disease was considered a divine punishment and the ill could only be taken care of in monasteries. Because medicine had a scholarly nature and was based on religious dogmas, its evolution stagnated during this period. Codex Vindobonensis 93, now to be found at the Vienna State Library, is a collection of miniature manuscripts important for the history of medicine.

There were two categories of physical monstrosity in the Middle Ages: people with malformations (Siamese twins, hermaphrodites, etc.) and apocalyptic monsters or bestiary creatures, which we now call hybrid or metamorphosed characters. Along with illustrated treatises on this topic, there were also curiosity chambers or cabinets, precursors of natural sciences museums. In fact, over the centuries, the monstrosity of the human body was an irresistible attraction for ordinary people, and trade in atypical human beings flourished, especially in the $18^{\text {th }}$ and $19^{\text {th }}$ centuries, when circuses presented to the general public various people with disabilities, as we call

\footnotetext{
${ }^{8}$ Hermann Haller, M. D., The Art of Diagnosis: Recognizing Disease in Paintings, August 2017, www.mdibl.org
} 
them today. In 1841, Phineas Taylor Barnum founded the American Museum in downtown New York, and from 1841 to 1868, it became the city's largest attraction, with an estimated 41 million visitors eager to see the oddities of human nature. In the $19^{\text {th }}$ century there came a wave of compassion for people with disabilities. This movement developed progressively and was a crucial moment, decisive for the way in which body deformities were to be perceived later on ${ }^{9}$.

Countless works of art and literature have addressed the issue of the non-acceptance of different people, one of them being Frankenstein, by Mary Shelley. Although the text deals with broader issues, such as the condition of the creator, of the scientist who wishes to be on a par with the divine, becoming a creator of life - a topic widely debated today in studies of medical ethics - the story also brings to the reader's attention the anxiety of the monster, of the different person in relation to others, his lack of integration, of acceptance, his struggle with loneliness and, implicitly, his alienation. The emotional needs of every human being are discussed. Over time, the perception of human deformities has changed, and medicine is interested in the recovery of these people and their reintegration into work and society.
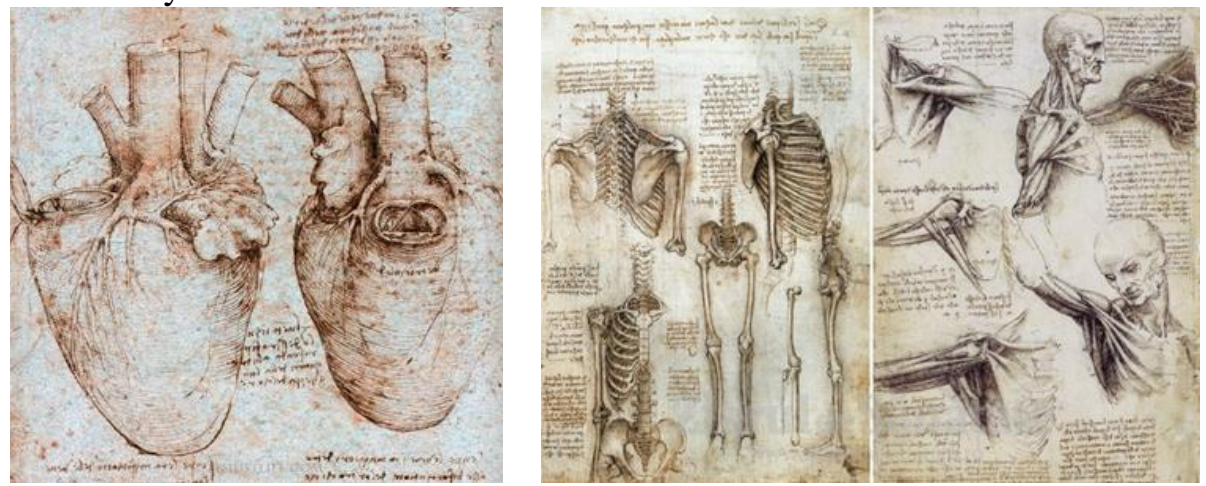

Fig. 3 Leonardo da Vinci, Studies in Human Anatomy

The appetite for the inexplicable was gradually replaced by scientific interest, present in anatomy books, and the first experiments date from the $15^{\text {th }}$ century and belong to Mondino de Luizzi, followed by the Renaissance masterpiece De Homini Corporis Fabrica, signed in 1543 by Andreeas Vesalius, a professor of anatomy from Padua, which presents the human skeletal, muscular, and cardiovascular systems. Leonardo da Vinci, the most fascinating figure of the Renaissance, dedicated an important part of his life to the study of human anatomy. Using dissection, Leonardo made hundreds of drawings and sketches of the structure of the human body, gathered in the two manuscripts kept at the Royal Library of Windsor Castle, now known as

\footnotetext{
${ }^{9}$ Stéphane Audoin-Rouzeau et al., op. cit., p. 106
} 
the Anatomical Manuscript A (1510-1511) and the Anatomical Manuscript B (1507-1508). Besides his impressive studies of human muscles and the skeleton, Leonardo was also fascinated by the structure of internal organs. Thus, he produces the first correct representation of the spine, the first description of liver cirrhosis, discovers the mystery of human embryo growth $^{10}$, and, fascinated by the structure of the heart, guesses several aspects that lay the foundations of important discoveries in 20th century cardiology. His studies describe for the first time the lesions caused by atherosclerosis and tuberculosis; he also discovers the functions of the eye and its connection with the brain (optic nerves and optic chiasm), the connections between muscles and nerves, and between nerves, the spinal cord, and the brain. He describes the organs, the digestive tract, the reproductive system, the inner ear, and the brain ${ }^{11}$. Two main reasons explain why Leonardo attracted the attention of physicians: he managed to organize descriptive, topographic, and even functional anatomy at a time when doctors ignored the structure of the human body, providing somatic and visceral structures presented spatially and scientifically, and defined the structure of reproductive organs and foetal development in all its physiological stages ${ }^{12}$.

After Leonardo, Michelangelo Buonarroti perfected the visual rendition of the human body, its mobility and facial expression. During the Renaissance, the interest in the human being, life, and, implicitly, disease and anatomy, increased considerably, as evidenced by the fact that the treatises on anatomy were illustrated by the great artists of that time.

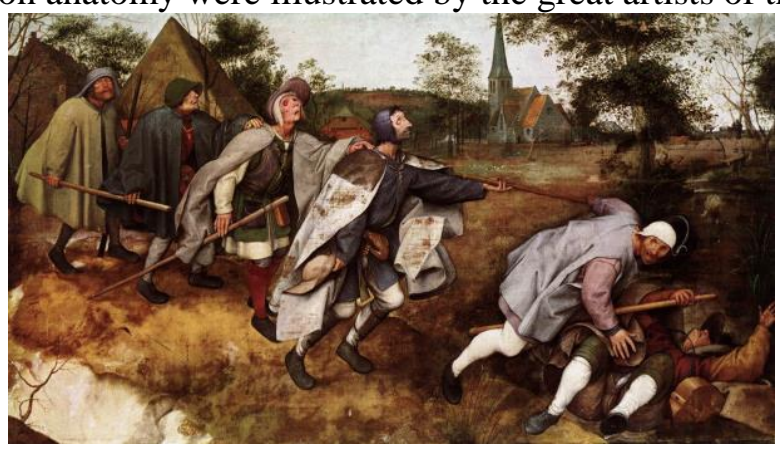

Fig. 4 Pieter Bruegel the Elder, Parable of the Blind

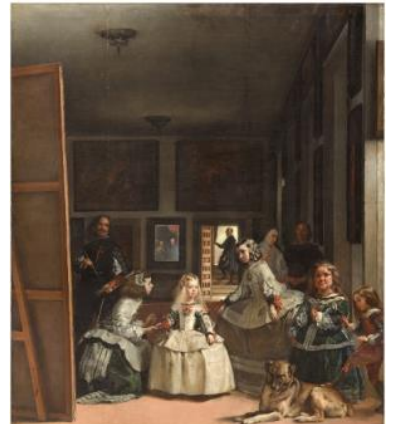

Fig. 5 Diego Velasquez, Las Meninas

In 1568, Pieter Bruegel the Elder painted the Parable of the Blind, a work based on a religious allegory referring to the lack of faith and its effects on the human body and spirit, expressed through several male figures who

\footnotetext{
${ }^{10}$ Ernst Gombrich, Istoria Artei, trad. Nicolae Constantinescu, Art Publishing, București, 2012, p. 294

${ }^{11}$ Mihai Pricop, Medicină și pictură. Semne, simptome, boli, procedee, personalități medicale redate prin tehnicile picturii, Dana Art, Iași, 2010, pag 43

${ }^{12}$ Mihai Dragomirescu, Medicina și arta plastică, Facla, Timișoara, 1986, p. 47
} 
are visually impaired. Along with the blind people's specific facial expression and insecure walking, Pieter Bruegel builds a descending compositional structure in order to emphasize not only the physical decay, but also the spiritual decline of man.

The famous work signed by Diego Velásquez in 1656, Las Meninas (Maids of honour), depicts a series of figures distributed on three planes: the king and queen of Spain, posing for a painting, are suggested as presences in a mirror hanging on the back wall, the painter and Infanta Margarita accompanied by her maids of honour and two characters suffering from dwarfism, a child and an adult woman, in the central position, and a male character behind a door in the background. Thus, Velásquez chooses to show the royal family with two little people, who centuries ago were seen as oddities of nature and as a source of entertainment as well. Dwarfism is also found in other works signed by Velásquez, such as Don Sebastian de Mora and The Idiot of Coria.

In the course of time, the medical act itself has been depicted in countless representations. The best known examples in this respect belong to Rembrandt van Rijn (1606-1669). Dr. Tulp's Anatomy Lesson (1632) was painted at an autopsy that involved physicians, students, and ordinary people, presented publicly in an anatomy amphitheatre, theatrum anatomicum ${ }^{13}$ (Pricop, 2010). In Dr. Johan Deijman's Anatomy Lesson (1656), Rembradt pays more attention to the corpse, recalling Mantegna's Lamentation over the Dead Christ. Although the original work was partially destroyed in a fire, and only a central fragment was preserved, compared to Dr. Tulp's Anatomy Lesson, which offers the foreground to the people participating in the dissection and the disciple-teacher relationship, this painting lays emphasis on the corpse, whose expression is exceptionally dramatic.

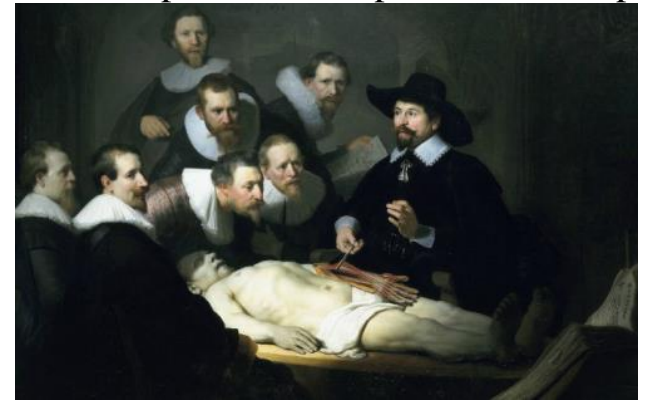

Fig. 6 Rembrandt van Rijn,

Dr. Tulp's Anatomy Lesson

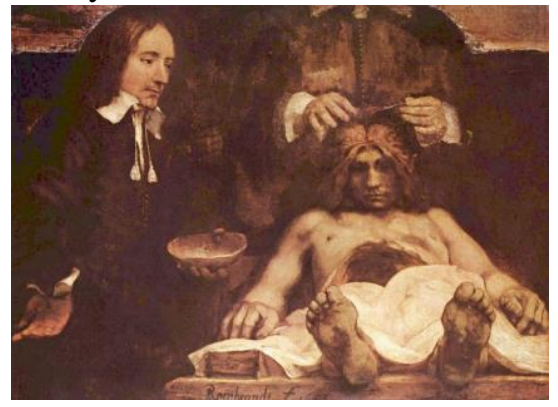

Fig. 7 Rembrandt van Rijn,

Dr. Johan Deijman's Anatomy Lesson

Not only does art have the ability to facilitate self-knowledge, but it also communicates to others who we really are (Botton, Armstrong, 2018). In the history of art there are many artists who used art as a method of

${ }^{13}$ Mihai Pricop, op. cit., p. 49 
expressing their own personal tragedies, their own physical and emotional suffering. Even if they lived at different times, on distinct continents and in distinct cultures, all these artists seem to have in common their suffering and their ability to transmit emotions, anxieties, pain. In their works, the rendition of the human body is a way of depicting moods, emotions, as if the painting were a mysterious mirror of the being (Jeudy, 1998). The correlation of emotional states and body attitudes or visual metaphors is an important feature of their works.

\section{Art as a way to exorcise one's own demons}

The Dutch post-impressionist painter Vincent Van Gogh is a particular case, an eloquent illustration of the condition of the suffering artist who manages to transpose his pain indirectly into his works of art. $\mathrm{He}$ succeeds in depicting his inner turmoil and anguish through vivid chromatics and its emotional impact, doubled by a strong, linear brushstroke. His selfportraits reflect the physical and mental pain that caused him to commit suicide when his was only 37 years old. In 1881 he fell ill with syphilis, a disease that he did not treat completely; he was depressed, epileptic, and schizophrenic. As he described them, the episodes of his condition included fits of anger, hallucination, confusion, fear, and memory loss, due not only to illness, but also to an addiction to absinthe. In 1889, during such an episode, he attacked the painter Paul Gauguin with a razor, but ended up cutting off a part of his own ear, which he packed and sent off to a prostitute. He then painted a self-portrait that shows him with a bandaged ear and serenity in his eyes. In April 1889, he admits himself to the Saint-Paul de Mausole psychiatric hospital of Saint Rémy, where he painted his famous Starry Night.

Van Gogh's case could also be analysed from a hereditary perspective: he seems to have inherited from his family if not a disease, at least a mental condition. His sister, Willemina, spent 40 years in a psychiatric asylum where she died of dementia, his brother Cornelius committed suicide, and Theo, the brother who took care of him throughout his life and with whom he often corresponded, died of paralyzing syphilis. Although no actual diagnosis exists, based on the analysis of his works, Van Gogh seems to have suffered from schizophrenia and glaucoma. After 1888, he started painting coloured shadows or halos around light sources, a symptom specific to glaucoma patients. In 1890 he painted the Church of Antwerp and the violence of his red and blue palette, as well as the strange depiction of the building lead specialists to the conclusion that he also suffered from schizophrenia. 


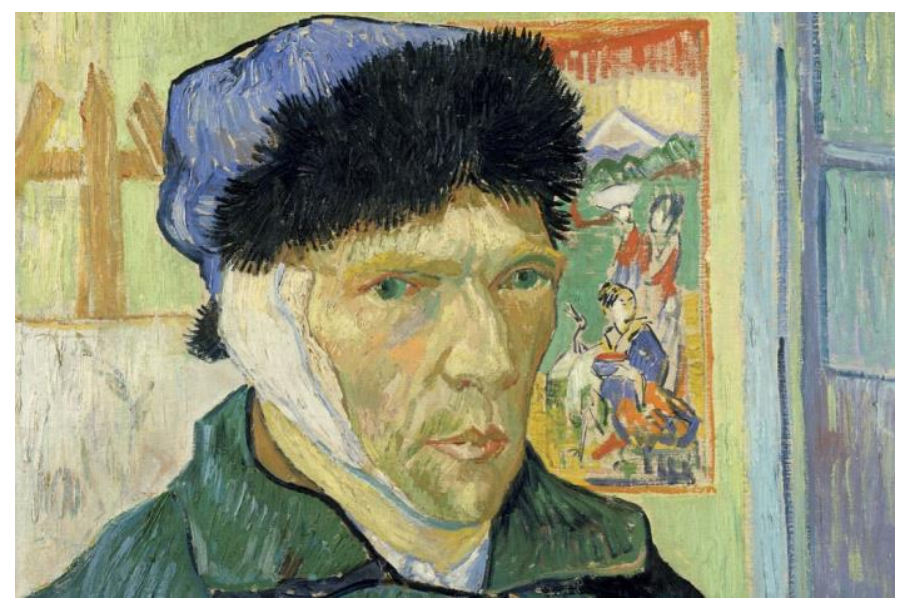

Fig. 8 Vincent van Gogh, Self-portrait with bandaged ear

Van Gogh's personality as a visionary, eccentric, volcanic artist was marked by the irreversible psychological condition from which he suffered, doubled by a social setting characterised by convention and indifference. His outward or inward-oriented aggressive behaviour, social dissatisfaction, and repeated attempts to control these aggressive impulses, his preference for loneliness and isolation, his bouts of melancholy and depression gradually lead him to suicide ${ }^{14}$.

Unlike other suffering artists, Henri de Toulouse-Lautrec (18641901) did not transfer his own pain into his works. Even if, alongside alcoholism, it marked his entire destiny, his condition, described by various terms (achondroplasia, polypiphyseal dysplasia, polypiphyseal dystrophy), is not to be found in the impressive body of work he produced throughout his 37 years of life. In fact, Toulouse-Lautrec was hiding great emotional trauma: a disgusting, disproportionate physical appearance that distanced him from ordinary people and made him prefer the company of the prostitutes and admirable cabaret dancers that he portrayed in his works.

Egon Schiele lived for a short time, from 1890 to 1918 , when he died of the Spanish flu together with his wife. In addition to the devastation of conflict, the First World War brought along an epidemic of the Spanish flu that decimated the people of Europe. Vienna, the city where the artist lived, was no exception. He came from a troubled family. His father suffered from hallucinatory psychosis and fits of anger, and the depressing atmosphere of his parents' house, doubled by a cold relationship with his mother, left their mark on young Egon. In fact, all his creation is marked by a remarkable understanding of the human being, his sexuality, and trauma. Most of his works are nudes and self-portraits characterized by overflowing, often sickly

\footnotetext{
${ }^{14}$ Mihai Dragomirescu, op. cit., p. 54
} 
and androgynous sexuality, but also by an expressionist mode of rendering the human body: strong-boned, pale or sickly red thin figures presented in contorted positions. He depicted the human being's instinctive side, the original intensity of sexual drive, and at the same time showed the body with all its weakness and misery ${ }^{15}$, emphasizing man's dual nature: life and death. Schiele's dramatic and graphic style, his contorted and deformed figures emphasize his personal appetite for the contrasts of human existence and the exploration of his own sexuality verging on the pathological but are also proof of his ability to observe his own individuality almost maniacally.

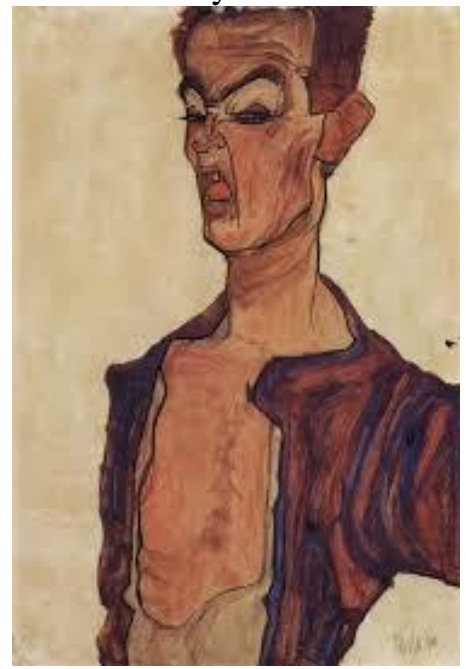

Fig. 9 Egon Schiele, Self-portrait with grimace

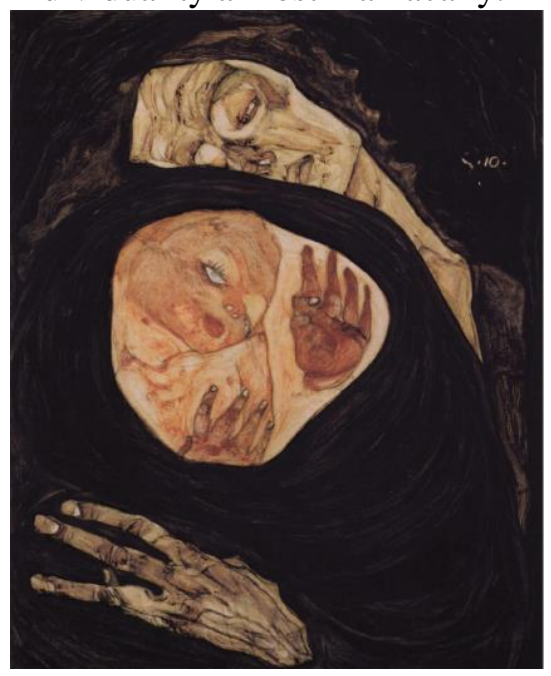

Fig. 10 Egon Schiele, Dead Mother

Seen as the greatest modern neurotic, Edvard Munch (1863-1944) managed to render the most shocking obsessions through pathological figures with morpho-psychological deformities ${ }^{16}$. His favourite theme was loneliness, despair and anguish in the face of aggressive disease and impossible integration into society. The physiognomy of his characters brim with fear and sadness, while postures and facial expressions, doubled by the palettes used, suggest the flight of someone chased by ghosts ${ }^{17}$. His work The Scream, painted in 1893, became a symbol of anxiety and pain. The artist described the act of creating it as follows: I sensed a scream running through nature, I thought I heard it. I painted this painting, I painted the clouds as if they were actual blood. The colours were screaming. As a matter of fact, Munch's work includes many works describing physical illness: The Sick Child (1907, Oslo National Gallery), considered one of his first masterpieces,

\footnotetext{
${ }^{15}$ Henry Pierre Jeudy, Corpul ca obiect de artă, Eurosong\&Book, Bucureşti, 1998, p. 86

${ }^{16}$ Mihai Dragomirescu, op. cit.

${ }^{17}$ Ibidem
} 
is a pale figure, rendered in shades of bluish grey and green. It is believed that his sister, Sophie, who died of tuberculosis, is the protagonist of several works, including The Sick Child. Munch also painted hospital scenes, funerals, and women beside the bed of dying people. Like Van Gogh and Egon Schiele, he was obsessed with his own face, which he depicted in many works. Like Van Gogh, he was cared for in a clinic for a mental illness, so it could be said that the artist translated his own fears, anxiety, and depression into his paintings ${ }^{18}$.

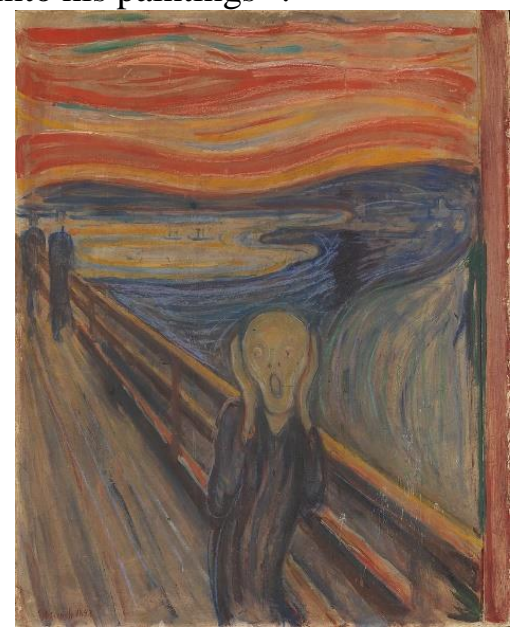

Fig. 11 Edvard Munch, The Scream

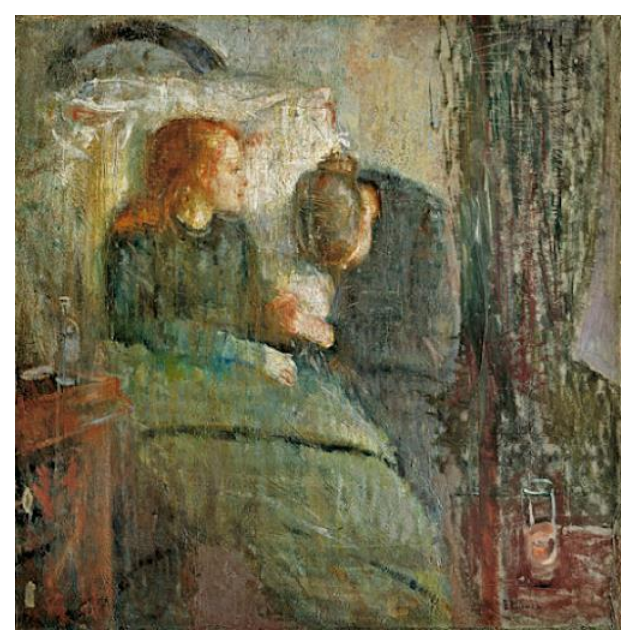

Fig. 12 Edvard Munch, The Sick Child

The expression of profound human feelings, doubled by social insecurity, war, hunger, disease, and poverty, is also found in the drawings of the German artist Käthe Kollwitz (1867-1945). Her works are very expressive and explore the great tragedies of mankind. In Woman with Dead Child, an engraving dating from 1903, the artist transposes the tragedy of a mother facing the death of her child, whom she embraces torn by grief. The work was created immediately after the artist's eldest son fell ill with diphtheria, a disease from which he survived, but which left deep wounds in the artist's soul. Thus, illness, infant mortality and the disaster they cause in a mother's soul became the central theme of her artistic creation, as in a premonition: her youngest son, Peter, died when he was only 21 fighting in the First World War.

The premonition was also at work, years later, in the case of Victor Brauner (1903-1966), a Jewish surrealist painter and poet born in Romania who created The Pictopoetry (with Ilarie Voronca). In 1930, eight years before losing an eye after having intervened in a dispute, he painted SelfPortrait with enucleated eye. This inspired the Argentine writer Ernesto Sabato, who included him in his book On Heroes and Tombs (1961).

\footnotetext{
${ }^{18}$ Mihai Pricop, op. cit., p. 67
} 


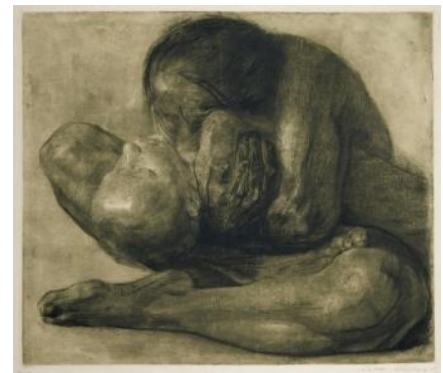

Fig. 13 Käthe Kollwitz, Woman with Dead Child
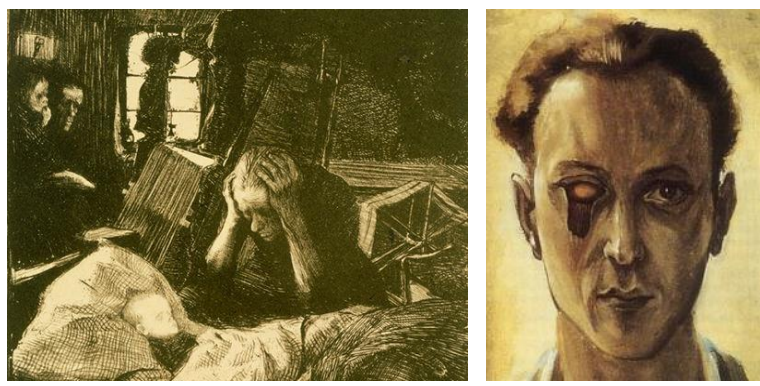

Fig. 14 Käthe Kollwitz, Fig. 15 Victor Brauner, Misery (Not
Self-portrait with) enucleated eye

The South American artist Frida Kahlo (1907-1954), whose artistic creation has returned in the public eye in recent years, is a special case. Her life was tormented by illness and suffering, on the one hand due to her having caught poliomyelitis at the age of nine, and, on the other hand, as a result of a serious car accident, which left her with fractures and internal injuries. Bedridden for long stretches of time, trapped in metal corsets, having undergone several spine surgeries, Frida discovers painting as a means to fight for survival, thus expressing her pain. Her body, mutilated after the accident, became the central object of her creation, as a symbol of her struggle for life, and physical and mental pain. Frida's paintings convey her ability to perceive and transpose into images the beauty and ugliness of life, her power to fight for life, to love, or to hate. Her relationship with a Mexican painter, the muralist Diego Rivera, was another source of pain in her life, doubled by the desire made impossible by physical inability to bear a child (she had several miscarriages), as a result of which she fell ill with depression. In Henry Ford Hospital or The Flying Bed, painted in 1932, Frida, in tears, is lying on the bed in a pool of blood, tied with red umbilical cords, gathered in her hand on her abdomen, by flying objects: a dead foetus, medical instruments placed on a stand, iliac bones.

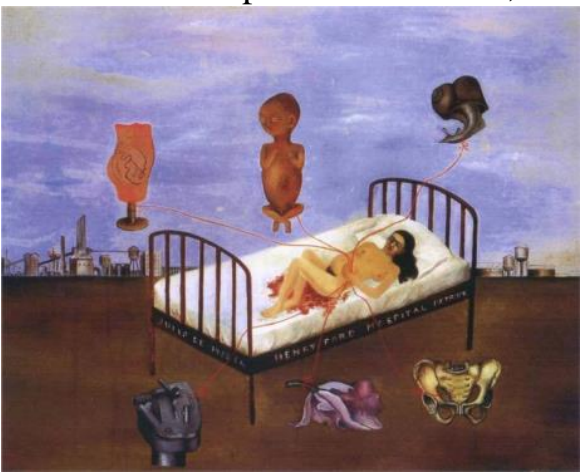

Fig. 16 Frida Kahlo, Henry Ford Hospital or the Flying Bed

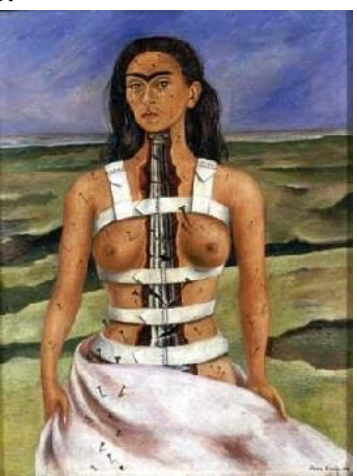

Fig. 17 Frida Kahlo, The Broken Column 
In the work Tree of Hope, Remain Strong, painted in 1946, Frida depicts herself in a chromatically divided universe: on the one hand, the beautiful woman dressed in a traditional Mexican costume, but holding a medical corset, is placed in the dark, cold part of the work. On the other hand, the woman lying on a hospital bed, showing her back bearing the traces of a surgery that has not been sutured yet, is placed in a more luminous setting. The two Fridas represent two lives: that of the bedridden, sick woman, and that of healthy Frida, who bears no trace of the accident.

One of the most famous works signed by Frida Kahlo is The Broken Column, painted in 1944, which shows the artist naked, as if she were having a medical examination. Her cracked body reveals an Ionic column, broken in several places, which replaces the spine, while the artist's torso is corseted, her skin is pierced by dozens of nails, and her eyes are in tears. This solitary figure, like all her self-portraits, is framed by an arid landscape, with cracks similar to those left by strong earthquakes, symbolizing the external force that changed her destiny during the accident.

My painting carries with it the message of pain [...]. Painting completed my life. I lost three children and a series of other things that would have fulfilled my horrible life. Painting substituted for all this, Frida Kahlo declared before dying from pulmonary embolism at only 47.

In Romanian art, the best-known example of a suffering painter is Ștefan Luchian, diagnosed with "locomotor ataxia", a spinal cord disease that affects the coordination of the limbs and leads to loss of reflexes and visual impairment ${ }^{19}$. Most of his masterpieces were painted after he got ill, with extraordinary sensitivity and strength.

In visual art, the human body presents several types of information. On the one hand, it renders beauty and ugliness, mirroring cultural ideals or concepts related to identity (race, gender, age, stage of life), form, health or disability, physical deformity. On the other hand, the body, body attitude and facial expression transmit information related to power, establish the limits of the body and emotional health. Artists have always been fascinated by the issue of life and death, pregnancy and birth, the similarities and differences between twins, illness and death.

In 1978, the French artist Orlan decided to film the entire surgery that she underwent in order to have an ectopic pregnancy terminated under partial anaesthesia. This moment in her life became the forerunner of a vast series of performances in which she used her own body as an instrument of art, exposing publicly her own aesthetic procedures. Her body becomes a collage of elements from famous works of art signed by Leonardo da Vinci or Botticelli while the artist calls herself a "work in progress" or "Saint Orlan". Deconstructing the idea of femininity and beauty, Orlan organizes real shows

${ }^{19}$ Ibidem, p. 92 
broadcast live in major museums or galleries, transforming the operating room into an art studio.

After receiving a cancer diagnosis in 1982, photographer Jo Spence builds works dedicated to feminism that criticize the idealized image of women in the media and advertising. The series entitled Picture of Health is devoted to the doctor-patient relationship, the invasive methods used to treat cancer, the confrontation with her own tragedy, the physical and emotional fight against this ultimately lethal disease.

The limits of the body, tested in the works of many artists including Orlan, Jo Spence, Marina Abramovic and Stelarc, are represented by the skin, an intermediate surface between the inside and the outside world ${ }^{20}$. From a philosophical perspective, the limit of the body is its finite ability to withstand pain and, finally, death ${ }^{21}$. In art, there are several recurring themes centred on the human body, such as: the death of the body versus the immortality of the soul, the young body as a symbol of beauty versus the aged body, the ability to control one's own body, self-preservation and survival instincts, the fight against disease, addictions and their impact on a person's health and state of mind.

Marina Abramovic's performative work is not related to disease, but her power of self-control over her body, her ability to educate her endurance, concentration, perception and will, are extraordinary. Their preparation involved an actual ritual, later patented as the Abramovic Method, in which the artist fasted, meditated for hours, isolated herself, did exercises of will, etc. The constant overcoming of physical and mental boundaries led to a sharpening of the senses (sight, hearing, smell). During her performative acts, which could last up to 12 hours, Marina Abramovic remained motionless, struggling with physical pain that was so intense that she almost lost consciousness. That experience is similar to a trance, which the artist describes like Dostoevsky in The Idiot. The moment before Prince Mishkin's epileptic seizure in Dostoevsky's novel corresponds to the sensations experienced by Abramovic, as she describes them in her memoir, Walk through walls: a feeling of weightlessness, a warm enveloping light, a state of perfect harmony with one's own being and with the entire Universe.

Last but not least, psychopathological art and art therapy have become the object of academic studies, and the importance of art therapy in the treatment and recovery of mentally ill patients has been demonstrated from a medical perspective. Over the decades, their drawings have been a source of inspiration and reflection for artists, to mention here only the raw art of Dubuffet or Wols and Paul Klee's interest in children's art and the art of the mentally ill.

\footnotetext{
${ }^{20}$ Henry Pierre Jeudy, op. cit., p. 65

${ }^{21}$ Diane Fortenberry, Rebecca Morrill (eds.), Body of Art, Phaidon Press Limited, London, 2015, p. 298
} 


\section{Conclusions}

Understanding the human body from an artistic perspective is in fact a combination of several factors. It is essential to gain knowledge of its forms and their mobility and, just as important, to understand the psychological traits of the individual. Art has served its purpose as long as, alongside ideas, representations, and technique, it manages to convey emotions as well. If we think of the works of art created over the centuries, it is not necessarily the correct representations of the body, from an anatomical point of view, that have the greatest impact on our mind and soul, but precisely the works of art that transmit the most deepest human feelings, emotions, states, experiences, agony and ecstasy.

"[...] We thinkers try to come closer to God by pulling the mask of the world away from His face. You come closer to Him by loving his Creation and re-creating it. Both are human endeavors, and necessarily imperfect, but art is more innocent..." (Hermann Hesse - Narcissus and Goldmund).

\section{List and source of illustrations}

Fig. 1 Agnolo Bronzino, Allegory of love, 1545. National Gallery, London

Fig. 2 Pieter Bruegel the Elder, The Triumph of Death, 1562, Prado Museum, Madrid Fig. 3 Leonardo da Vinci, Studies in Human Anatomy, Royal Library, Windsor Castle

Fig. 4 Pieter Bruegel the Elder, Parable of the Blind, 1568, Louvre Museum, Paris

Fig. 5 Diego Velasquez, Las Meninas, 1656, Prado Museum, Madrid

Fig. 6 Rembrandt van Rijn, Dr. Tulp's Anatomy Lesson, 1632, Mauritshuis Museum, The Hague

Fig. 7 Rembrandt van Rijn, Dr. Johan Deijman's Anatomy Lesson, 1656

Fig. 8 Vincent van Gogh, Self-portrait with bandaged ear, 1889, Courtauld Gallery, London

Fig. 9 Egon Schiele, Self-portrait with grimace, 1910, Leopold Museum, Vienna

Fig. 10 Egon Schiele, Dead Mother, 1910, Leopold Museum, Vienna

Fig. 11 Edvard Munch, The Scream, 1893, National Gallery and Munch Museum, Oslo, Norway

Fig. 12 Edvard Munch, The Sick Child, 1907, National Gallery and Munch Museum, Oslo, Norway

Fig. 13 Käthe Kollwitz, Woman with Dead Child, 1903, Bremen Kunsthalle, Germany

Fig. 14 Käthe Kollwitz, Misery (Not), 1897, Smith College Museum of Art

Fig. 15 Victor Brauner, Self-portrait with enucleated eye, 1930

Fig. 16 Frida Kahlo, Henry Ford Hospital or the Flying Bed, 1932, Dolores Olmedo Patino Museum, Mexico City

Fig. 17 Frida Kahlo, The Broken Column, 1944 


\section{Bibliography}

Abramoviç, Marina, Incălcând toate granițele, Pandora M, București, 2019 Audoin-Rouzeau, Stéphane, Baecque, Antoine de, Becker, Annette, Courtine, Jean-Jacques, Keck, Frédéric, Michaud, Yves, Moulin, Anne Marie, Ory, Pascal, Rabinow, Paul, Sohn, Anne-Marie, Suquet, Annie, Vigarello, Georges, Istoria corpului, vol.III, Mutațiile privirii. Secolul XX, Art Publishing, București, 2009

Bell, Julian, Oglinda lumii. O nouă Istorie a artei, Vellant, București, 2007

Bîlbîe Nosec, Ionela, Arta - bucurie și suferință, Viața Medicală Românească, București, 2005

Bockl, M. Christine, Plague Imagery as Metaphor for Heresy in Ruben's The Miracles of Saint Francis Xavier, Sixteen Century Journal, XXVI.4 (1996), 979-995 JSTOR.

Botton, Alain de, Armstrong, John, Arta ca terapie, Vellant, București, 2019

Corbin, Alain, Courtine, Jean-Jacques, Vigarello, Georges (eds.), Istoria corpului, vol. II, De la revoluția Franceză la Primul Război Mondial, Art Publishing, București, 2009

Dragomirescu, Mihai, Medicina și arta plastică, Facla, Timișoara, 1986

Eco, Umberto (ed.), Istoria Urâtului, Rao, București, 2007

Fortenberry, Diane, Morrill, Rebecca (coord.), Body of Art, Phaidon Press Limited, London, 2015

Fride Carrassat, Patricia, Marcadé, Isabelle, Mișcări artistice în pictură, Rao, București, 2007

Gombrich, Ernst, Istoria Artei, trad. Nicolae Constantinescu, Art Publishing, București, 2012

Haller, Hermann, M. D., The Art of Diagnosis: Recognizing Disease in Paintings, August 2017, www.mdibl.org

Hartnell, Jack, Medieval Bodies. Life, Death and Art in the Middle Ages, Profile Books Ltd, Wellcome Collection, London, 2018

Jeudy, Henry Pierre, Corpul ca obiect de artă, Eurosong\&Book, București, 1998

Pricop, Mihai, Medicină și pictură. Semne, simptome, boli, procedee, personalități medicale redate prin tehnicile picturii, Dana Art, Iași, 2010

Souter, Gerry, Kahlo, Editura Aquila 93, Oradea, 2008, trad. Ana Maria Hodorog Steiner, Reindard, Egon Schiele. 1890-1918. L'âme nocturne de l'artiste, Taschen, 2012 